\title{
Biochemical, Pharmacological, and Therapeutic Effects of Triple Antihypertensive Therapy with Amlodipine, Valsartan and Hydrochlorothiazide in Elderly Hypertensive Patients with Calcium Phosphate Nephrolithiasis
}

\author{
DAN SIMION CIPU\#, DANIELA CIPU*, DELIA BERCEANU VADUVA*, MARCEL BERCEANU VADUVA\#, VICTOR DUMITRASCU, \\ MATILDA RADULESCU, DANA VELIMIROVICI \\ University of Medicine and Pharmacy Victor Babes, 2 Eftimie Murgu Sq., 300041, Timisoara, Romania
}

\begin{abstract}
Antihypertensives are widely prescribed in the geriatric population and could influence kidneystone risk but many aspects are still unknown. Thiazides are used to control lithogenic factors and recurrences in patients with calcium lithiasis. The aim of our study was to evaluate the relationship between essential arterial hypertension and stone disease, by studying the pharmaco-therapeutic effects of a fixed-dose combination of amlodipine + valsartan + hydrochlorothiazide (Aml + Val + HCTZ) 10/320/25 mg, on the urinary stone risk in a study group of hypertensive geriatric patients. A longitudinal, randomized, three years follow-up clinical and experimental study was conducted during J une 1, 2014 - July 31, 2017. A number of 60 eligible geriatric patients, treated only with a fixed-dose combination of Aml + Val + HCTZ 10/320/25 mg, as a single-tablet, were enrolled in the study. All the patients were stone formers, with more than three episodes of crystalluria in the last two years. The patient's age ranged between 55 and 65 years. Exclusion criteria: patients with heart failure, kidney chronic diseases, use of drugs known to affect renal function, patients with multi-morbidities. All patients had similar blood pressure values, and tension was well controlled throughout the whole study period. In the elderly patients, the treatment with $25 \mathrm{mg} /$ day of hydrochlorothiazide (from the combination of Aml $+\mathrm{Val}+\mathrm{HCTZ} 10 / 320 / 25 \mathrm{mg}$ ) has a beneficial and prolonged efficacy in treatment of recurrences in patients with calcium oxalate and phosphate lithiasis Our study reveals that in the elderly patients with hypertension and nephrolithiasis as a comorbidity, thiazides - $25 \mathrm{mg} /$ day of hydrochlorothiazide (from the combination of Aml + Val + HCTZ 10/320/25 mg) has a beneficial effect in order to control lithogenic factors and recurrences in patients with calcium phosphate lithiasis.
\end{abstract}

Keywords: fixed-dose combination of Aml + Val + HCTZ10/320/25 mg, hydrochlorothiazide geriatric patient, nephrolithiasis

Research over the past decade has shown that triple fixed-dose combination of amlodipine + valsartan + hydrochlorothiazide (Aml + Val + HCTZ) 10/320/25 mg has beneficial effects and is safe for the elderly hypertensive patients [1-3].

Geriatric patients have a lot of co-morbidities that make antihypertensive therapy even more difficult. Nephrolithiasis (kidney stone) has a prevalence and incidence that has increased markedly in elderly population [4]. Studies by Knoll T and cow orkers have revealed that about $10 \%-20 \%$ of all patients with nephrolithiasis are older than 65 years [5].

Antihypertensives are widely prescribed in the geriatric population and could influence kidney stone risk butmany aspects are still unknown [6].

The pathogenic link between hypertension and renourinary stone disease is not fully understood. A possible association between nephrolithiasis and stone risk profile, including supersaturation of lithogenic salts, hypertension has been suggested by a high number of studies $[7,8]$.

A significant correlation between arterial pressure and calcium excretion has been revealed by many researchers especially in older patients when hypertension is associated with excessive body weight [9-12].

\section{Objectives}

The aim of our study was to evaluate the relationship between essential arterial hypertension and stone disease, by studying the pharmaco-therapeutic effects of a fixeddose combination of Aml + Val + HCTZ 10/320/25 mg, on the lithogenous risk in a study group of hypertensive geriatric patients.

\section{Experimental part}

Material and method

Study design

A longitudinal, randomized, three years follow-up clinical and experimental study was conducted during June 1 , 2014 - July 31, 2017. A number of 60 eligible geriatric patients, treated only with a fixed-dose combination of Aml + Val + HCTZ 10/320/25 mg, as a single-tablet, were enrolled in the study. All the patients were stone formers, with more than three episodes of crystalluria in the last two years. The patient's age ranged between 55 and 65 years.

The patients received fixed-dose combination of $\mathrm{Aml}+$ Val + HCTZ 10/320/25 mg, as a single-tablet once-daily during the three years study period.

In order to participate in this survey, all 60 patients expressed written consent, according to the criteria set out in the Helsinki Declaration [13].

Inclusion criteria

In the study were enrolled geriatric patients with diagnosis of arterial hypertension according to current European guidelines, with previous calcium phosphate urolithiasis. 


\section{Exclusion criteria}

Exclusion criteria: patients with heart failure, kidney chronic diseases, use of drugs known to affect renal function, patients with multi-morbidities [13-17].

Fourier-transform infrared spectroscopic analysis

Infrared absorption spectra were traced with a JASCO

FT-IR 4200 device (with automatic reading of the absorption bands, interferometer Michelson $45^{\circ}$ ). The measuring range was set to $4000-600 \mathrm{~cm}^{-1}$. Spectra were taken at the normal temperature and pressure existing in the laboratory. The smoothness of the line of $100 \%$ T was $100 \pm 1.0 \%$ T (repeating the continuous measurement).

The samples were prepared after $\mathrm{KBr}$ pelleting, by mixing the ground bone with $\mathrm{KBr}(1 \mathrm{mg}$ sample/100 mg $\mathrm{KBr}$ ) under vacuum, as usually applied for Fourier-transform infrared spectroscopic studies [18].

The crystalline hydroxyapatite was obtained from amorphous calcium phosphate at $\mathrm{pH}$ 8.5; preparation was done by the method of Boskey and Posner [19] .

\section{Urinary stone risk evaluation}

Supersaturation calculations for calcium oxalate, calcium phosphate, and struvite were obtained using the technique introduced in 1977 by Finyalson B [20].

Statistical analyses were performed using the SPSS software package (version 23.0 for Windows, SPSS Inc, Chicago, IL.). Results were expressed as mean and standard deviation. The difference was considered significant when the $p$-value $<0.05$.

\section{Results and discussions}

In the study were enrolled 60 elderly patients, respectively 25 women (41.67\%) and 35 men (58.33\%). Of the 60 cases evaluated, at the beginning of the study, 8 patients (13.33\%) had renal urinary microlithiasis and 52 patients $(86.67 \%)$ presented macroscopic renal urinary calculi.

All patients had similar blood pressure values, and tension was well controlled throughout the whole study period ( $p>0.05$ ).

The age of the patients enrolled in the study ranged between 55 and 65 years (table 1 ).

Among the macroscopic kidney stones, 13 cases $(21.67 \%)$ were eliminated spontaneously, 17 cases (28.33\%) were crushed by extracorporeal litothrithy and $22(36.67 \%)$ required surgical removement.

Each patient underw ent a complexe examination plan, with anamnestic, clinical and paraclinical steps, as in the example bellow (fig. 1).

The Fourier-transform infrared spectra revealed seven spectral bands,as pointed out in table 2. There are revealed two spectral bands specific to phospho-calcic compounds - the specific band for carbonatapatite - at $793.56 \mathrm{~cm}^{-1}$ and that of hidroxyapatite at $633.50 \mathrm{~cm}^{-1}$, in a female patient with nephrolithiasis since four years and hypertension since only two years, receiving a fixed-dose combination of Aml + Val + HCTZ 10/320/25 mg, as a single-tablet once-daily.

\begin{tabular}{|c|c|c|c|c|c|c|c|}
\hline Studied parameter & Nr. & $\begin{array}{c}\text { L } \\
\text { min. }\end{array}$ & $\begin{array}{c}\text { L } \\
\text { Max. }\end{array}$ & MA & Me & SD & SE \\
\hline Patients age & 60 & 55 & 65 & 61.17 & 61.00 & 2.60 & 0.34 \\
\hline
\end{tabular}

Nr. -No. of subjects; L min. -minimum limit; L Max -maximum limit; MA -aritmetic range;

Me -median; SD -standard deviation; SE -standard error.

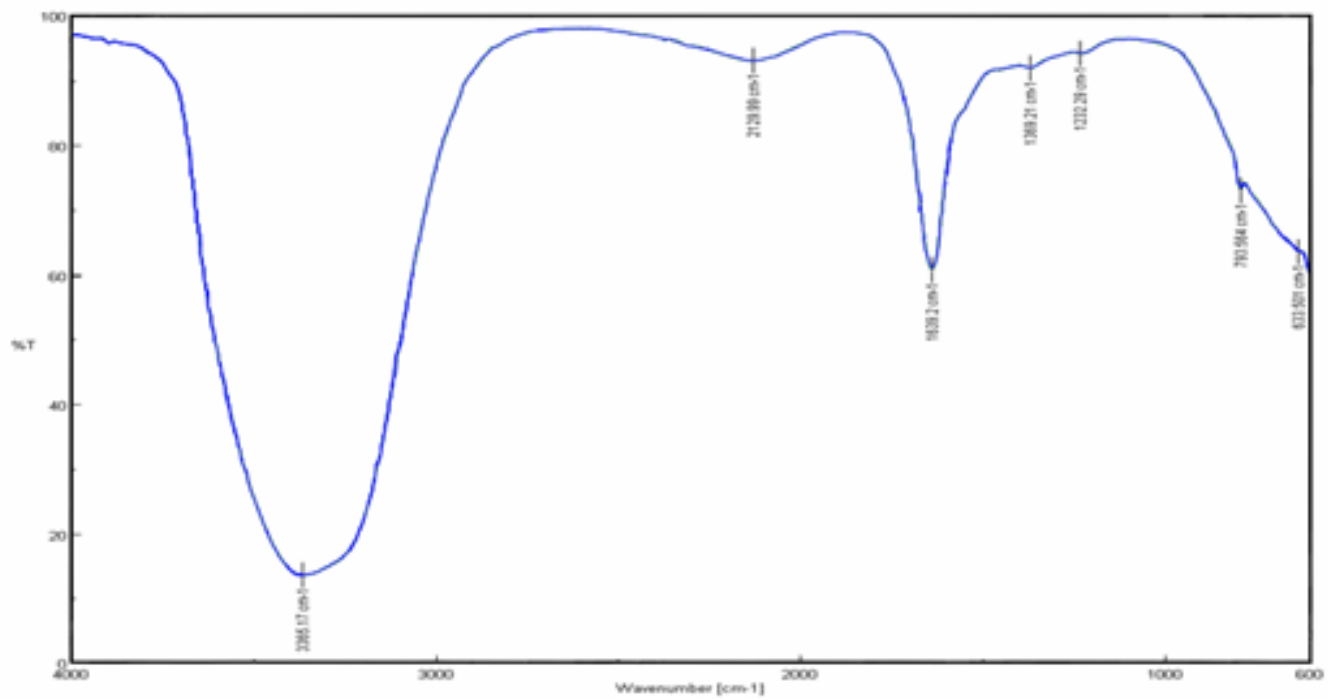

Fig.1. Fourier-transform infrared spectroscopic analysis of a renal calculus from patient M.A., 63 years old with hypertension and nephrolithiasis since four years

\begin{tabular}{|c|c|c|c|}
\hline $\begin{array}{l}\text { Spectral } \\
\text { domain }\left(\mathrm{cm}^{-1}\right)\end{array}$ & Compound & Clinical features & Laboratory findings \\
\hline$\overline{3365,17}$ & water & \multirow{6}{*}{$\begin{array}{l}\text { Hypertension treated with } \\
\text { Aml + Val + HCTZ } \\
\text { 10/320/25 mg } \\
\text { Phospho-calcic urolithiasis } \\
\text { - Renal colic }\end{array}$} & \multirow{6}{*}{$\begin{array}{l}\text { Recurrent stone former } \\
\text { Urinary phosphorus } 890 \mathrm{mg} / \text { day } \\
\text { Calciuria } 216 \mathrm{mg} / \text { day } \\
\text { Oxaluria } 33 \mathrm{mg} / \text { day }\end{array}$} \\
\hline 2129,99 & $\overline{\overline{\mathrm{CO}_{2}}}$ & & \\
\hline$\overline{1639,20}$ & $\begin{array}{l}\text { lipids and } \\
\text { proteines }\end{array}$ & & \\
\hline$\overline{1369,21}$ & Amide III & & \\
\hline$\overline{1232,29}$ & $\overline{\mathrm{HA}}$ & & \\
\hline $\begin{array}{l}793,56 \\
633,50\end{array}$ & $\begin{array}{c}\mathrm{CO}_{3}=\mathrm{CA} \\
\mathrm{HA}\end{array}$ & & \\
\hline
\end{tabular}
ANALYSIS OF THE PATIENTS AGE ENROLLED IN THE STUDY (60 PATIENTS WITH HYPERTENSION AND NEPHROLITHIASIS)

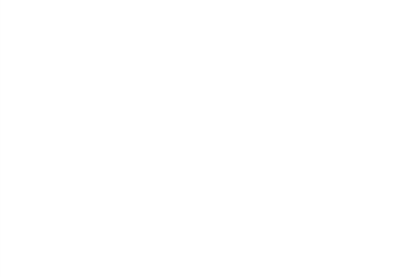

Table 2

FOURIER-TRANSFORM INFRARED SPECTROSCOPIC ANALYSIS, CLINICAL FEATURES AND URINARY STONE RISK EVALUATION IN PATIENT M.A., 63

YEARS OLD WITH

HYPERTENSION AND NEPHROLITHIASIS SINCE FOUR YEARS 
In all the geriatric patients enrolled in the study, one revealed that fixed-dose combination of Aml + Val + HCTZ $10 / 320 / 25 \mathrm{mg}$ is very useful in reducing blood pressure and monitoring it in case of long-term administration, due to optimal pharmacokinetic profile of the three component drugs, as described for the first time by Coulhan and coworkers in 2009 [21].

Among the patients taken in the study, $36(60 \%)$ were recurrent stone formers therefore they had a high urinary stone risk.

In the whole, the treatment with Aml + Val + HCTZ 10/ $320 / 25 \mathrm{mg}$ reduced the urinary stone risk by lowering the main parameters which composed it, as following:

-urinary phosphorus (mg/day) - from $904 \pm 32$ at $612 \pm 18$ (at the end of the study);

-calciuria (mg/day) - from $256 \pm 14$ at $148 \pm 28$ (at the end of the study);

-oxaluria (mg/day) - from $34 \pm 18$ at $21 \pm 16$ (at the end of the study).

The participants were followed for the occurrence of a kidney stone event while maintaining continuous usage on their drug, but no calculus was reported.

In accordance with recent valuable researches undertaken in this scientific field, we tried to reveal and understand the comorbidity of patients with arterial hypertension and nephrolithiasis [22]. In this context, our results were in accordance with Fernández-Rodríguez and co-workers, who pointed out that in the elderly patients, the treatment with $25 \mathrm{mg} /$ day of hydrochlorothiazide (from the combination of Aml + Val + HCTZ 10/320/25 mg) has a beneficial and prolonged efficacy in treatment of recurrences in patients with calcium oxalate and phosphate lithiasis [23].

\section{Conclusions}

Our study reveals that in the elderly patients with hypertension and nephrolithiasis as a comorbidity, thiazides - $25 \mathrm{mg} /$ day of hydrochlorothiazide (from the combination of Aml + Val + HCTZ 10/320/25 mg) have a beneficial effect in order to control lithogenic factors and recurrences in patients with calcium phosphate lithiasis.

\section{References}

1.DIACONU C., Comorbidities of hypertensive patients: are there differences between men and women? Archives of the Balkan Medical Union, 51(3), 2016, p. 307-310.

2.CIPU D.S., CIPU D., BUCUR A., DUMITRASCU V., Interference between antihypertensive therapies and zinc bioavailability in geriatric patients, Medicine in Evolution, XXIII(2), 2017, p. 107-111.

3.CIPU D.S., CIPU D., BUCUR A., MATUSZ A.A., DUMITRASCU V., Beneficial effects of triple antihypertensive therapy with amlodipine, valsartan and hydrochlorothiazide on copper status in a trial of geriatric patients in southwestern Romania, Archives of the Balkan Medical Union, 52(3), 2017, p. 306-309.

4.MOUDI E., HOSSEINI S.R., BIJ ANI A., Nephrolithiasis in elderly population; effect of demographic characteristics, Journal of Nephropathology, 6(2), 2017, p. 63-68.

5.KNOLL T., SCHUBERT A.B., FAHLENKAMP D., LEUSMANN D.B., WENDT-NORDAHL G., SCHUBERT G., Urolithiasis through the ages: data on more than 200,000 urinary stone analyses, J. Urol., 185(4), 2011, p. 1304-1311.

6.KATES M., MATLAGA B.R., Stones in the Elderly, Curr Geri Rep. 3(1), 2014, p. 14-18.
7.DUSE, A.O., BERCEANU VADUVA, D., NICOLOV, M., TRANDAFIRESCU, C., BERCEANU VADUVA, M., CEVEI, M., HEGHES, A., Biostatistical Analysis and Possible Forecasting of Relationship Between Uric Acid and Specific Laboratory Tests in Cases of Gouty Arthritis, Rev. Chim. (Bucharest), 68, no. 6, 2017, p. 1234-1241.

8.STANCU, A., GHISE, A., PENTEA, M., BERCEANU VADUVA, D.M., VELIMIROVICI, D.E., CARPINISAN, L., ROMEO, C., Chylothorax Consecutive Heartworm Disease in Dog, Mat. Plast., 54, no. 4, 2017, p. 785-787.

9.BARTOLETTI R., CAI T., MONDAINI N., MELONE F., TRAVAGLINI F., CARINI M., Epidemiology and risk factors in urolithiasis, Urol Int., 79(Suppl 1), 2007, p. 3-7.

10.PETRESCU H.P., DINU G., NODITI G., CRAINA M., BERCEANU VADUVA D., BERCEANU VADUVA M., VERMESAN D., Morphometric analysis of bone vascular channels during the biointegration of autologous bone grafts, Romanian J. of Morphology and Embriology 54(3), 2013, p. 613-616.

11.PETRESCU H.P., DINU G., BERCEANU VADUVA D., BERCEANU VADUVA M., Microdensity and morphometric analysis of autologous bone grafts cells, Romanian J. of Morphology and Embriology 54(2), 2013, p. 395-398.

12.RUSU, M.C., POP, E., Fenestrated vertebral artery, ANATOMICAL SCIENCE INTERNATIONAL, 88(4), 2013, pp.249-253

13.*** World Medical Association Declaration of Helsinki: ethical principles for medical research involving human subjects, JAMA 310(20), 2013 Nov 27, p. 2191-2194.

14.CIPU, D., BERCEANU VADUVA, D.M., VELIMIROVICI, D.E., CIPU, D.S., Immunohistochemical Tumor-related Aspects in Diagnostic Mediastinal Lymph Node Extension in Broncho-pulmonary Carcinoma, Rev. Chim. (Bucharest), 67, no. 6, 2016, p.1218-1223.

15.STANCU, A., ROMEO, C., AHMADI, M., CARPINISAN, L., GHISE, A., PENTEA ,M., BERCEANU VADUVA ,D.M., Hematoxylin - eosin-methylene Blue Staining in a Dog Hemangiosarcoma Case, Mat. Plast., 52, no. 4, 2015, p. 514-515.

16.STANCU, A., CARPINISAN L., GHISE, A., PENTEA, M., BERCEANU VADUVA, D.M., VELIMIROVICI, D.E., ROMEO, C., Hematoxylin-eosinmethylene Blue Staining in a Dog Hepatic Amyloidosis Case, Mat. Plast., 54, no. 3, 2017, p. 546-548.

17.BERCEANU VADUVA, D.M., VELIMIROVICI ,D.E., BERCEANU VADUVA M.M., STANGA, L., PETRESCU, H., RADA, M., CIPU, D., BERCEANU VADUVA, B.M., RADULESCU, M., Phenotypic Study and Sensitivity to Anti-Infective Chemotherapy of Bacterial Strains Isolated from Cutaneous-Mucosal Infections, Mat. Plast., 55, no. 3, 2018, p. 372-375. 18.GOURION-ARSIQUAUD S., LUKASHOVA L., POWER J., LOVERIDGE N., REEVE J., BOSKEY A.L., Fourier transform infrared imaging of femoral neck bone: reduced heterogeneity of mineral-to-matrix and carbonate-to-phosphate and more variable crystallinity in treatmentnaive fracture cases compared with fracture-free controls, J Bone Miner Res, 28, 2013, p.150-161.

19.LOTHAR T., Clinical laboratory diagnostics: use and assessment of clinical laboratory results, Frankfurt am Main, TH-Books, 2018.

20.COULHAN D.A., LACOURCIERE Z., CHIANG Y.T., GLAZER R.D., Triple antihypertensive therapy with amlodipine, valsartan and hydrochlorothiazide: a randomized clinical trial, Hypertension, 54(1), 2009, Jul, p.32-39.

21.FINLAYSON B., Calcium stones: Some physical and clinical aspects. In Calcium Metabolism in Renal Failure and Nephrolithiasis, edited by David DS, New York, John Wiley and Sons, 1977, p. 337-382.

22.ALEXANDER R.T., MCARTHUR E., JANDOC R., WELK B., HAYWARD J.S., J AIN A.K., BRAAM B., Antihypertensive medications and the risk of kidney stones in older adults: a retrospective cohort study, Hypertens Res., 40(9), 2017, Sep, p. 837-842.

23.FERNANDEZ-RODRIGUEZ A., ARRABAL-MARTIN M., GARCIA-RUIZ M.J., ARRABAL-POLO M.A., PICHARDO-PICHARDO S, ZULUAGAGOMEZ A., The role of thiazides in the prophylaxis of recurrent calcium lithiasis, Actas Urol Esp., 30(3), 2006, Mar, p. 305-309.

Manuscript received: 3.11 .2018 